DOI https://doi.org/10.30525/978-9934-26-111-4-47

\title{
ОСОБЛИВОСТІ РЕАЛІЗАЦІЇ ГЕНЕТИЧНОГО ПОТЕНЦАЛУ ЗЕРНОВИХ КУЛЬТУР В СТЕПУ УКРАЇНИ
}

Іщенко В. А.

кандидат сільськогосподарських наук, заступник директора з наукової роботи Інститут сільського господарства Степу Наиіональної академії аграрних наук України

\author{
Козелець Г. М. \\ кандидат сільськогосподарських наук,
} завідувач лабораторії науково-інновачійного впровадження, первинного та елітного насінництвв Інститут сільського господарства Cтепу Національної академії аграрних наук України

Умрихін Н. Л.

кандидат сільськогосподарських наук, завідувач відділу рослинництва

Інститут сільського господарства Степу

Національної академії аграрних наук Украӥни

с. Созонівка, Кіровоградська область, Украӥна

Одним із основних факторів одержання високих і стабільних урожаїв сільськогосподарських культур $\epsilon$ добір сортів, які здатні забезпечувати стабільний збір зерна за будь-яких погодних умов. Особливо важливо в кожному господарстві вирощувати 2-3 сорти, які відрізняються групою стиглістю та господарсько-корисними властивостями, що гарантує отримання максимального рівня продуктивності [1]. Поширення та комерційний обіг нових сортів $є$ важливими чинниками забезпечення продовольчої безпеки України [2]. Особливістю будь-якого сорту $є$ сукупність властивостей, що визначають його придатність для вирощування в різних грунтово-кліматичних умовах, а тому правильний вибір сорту має вирішальне значення [3].

Для виділення високоадаптивних сортів для мінливих метеорологічних умов відповідної еколого-географічної зони потрібно проводити оцінку екологічної пластичності за врожайністю $[4,5]$. Рівень урожайності с.-г. культур залежить від впливу контрастних 
грунтово-кліматичних умов та елементів технології. Для отримання високих і стабільних показників урожайності потрібно створити сприятливі умови для успішного росту і розвитку рослин шляхом запровадження інтенсивних технологій. За різких коливань погодних умов, важливим показником для сортів зернових культур є їхня стійкість до стресу, рівень якої визначається за різницею між мінімальною і максимальною врожайністю (Уmin - Уmax). Цей параметр має негативне значення, i чим менша величина, тим вища стійкість сорту до стресу [6]. Середня врожайність сортів у контрастних умовах $(\mathrm{Y} \min +\mathrm{Ymax}) / 2$ характеризує їхню генетичну гнучкість $\mathrm{i}$ чим вище значення даного показника, тим більша відповідності між генотипом сорту і умовами середовища [7]. Коефіцієнт варіації (V) характеризує стійкість ознаки в умовах середовища, що змінюються. Математичну обробку випробування сортів зернових культур за продуктивністю в умовах Північного Степу України проводили дисперсійним методом, статистичну - за допомогою програми Microsoft Excel 3 визначенням середніх, мінімальних (min), максимальних (max) значень і розмаху варіювання (R).

Сорти пшениці озимої, які придатні для вирощування в зоні Степу, яка характеризується гострим дефіцитом вологи, високими температурами продовж періоду вегетації у весняно-літній період повинні відзначатися достатньо високою стійкістю до морозів, посухоі жаростійкістю, високою генетичною стійкістю до хвороб і шкідників, тривалість вегетаційного періоду на рівні середньоранніх середньостиглих із потенціалом урожайності зерна не менше 10-12 т/га та якістю на рівні сильних і надсильних пшениць. Дослідженнями в Інституті сільського господарства Степу НАAН, який знаходиться в зоні Північного Степу України продовж 2016-2020 рр. встановлено, що сорти різного екологічного походження формували урожайність від 5,27 т/га до 8,67 т/га, розмах варіювання $\mathrm{R}(\max -\min )=3,40 \mathrm{~T} /$ га, за коефіцієнта варіації 14,0\%. Середня врожайність сортів пшениці озимої м'якої у контрастних умовах років досліджень (Уmin + У $\max )$ / 2 змінювалась від 6,26 т/га (2017р.) до 8,68 т/га (2019 р.), а реалізація генетичного потенціалу продуктивності сортів становила 51,6-72,1\%. За однакових умов вирощування сорти, які мали високий адаптивний потенціал забезпечували реалізацію генетичного потенціалу продуктивності від 6,96 т/га або 58,0 \% (2017 р.) до 10,26 т/га або 85,5 $\%$ (2019 р.). Найвищою генетичною гнучкістю $\left(\mathrm{У}_{\min }+\mathrm{Y} \max \right) / 2 \mathrm{i}$ найбільшою відповідністю до умов вирощування Північного Степу відзначались сорти пшениці озимої м'якої Мудрість одеська $(8,01$ т/га), Традиція одеська $(8,03$ т/га), Перепілка $(8,51$ т/га), Постать одеська 
$(8,41$ т/га), Нота одеська $(8,11$ т/га), Сториця $(8,72$ т/га), Оранта одеська $(8,83$ т/га), Дума одеська $(8,49$ т/га), Славен $(8,02$ т/га), Октава $(8,30$ т/га), Наснага (8,71 т/га), СГІ-100 (8,50 т/га), Вежа Миронівська $(8,14$ т/га) та МІП Ассоль $(8,30$ т/га). При цьому, вищим показником стресостійкості серед досліджуваних сортів $(\min -\max )=0,28-0,92$ т/га відзначались Перепілка, Нота одеська, СГІ-100, Грація Миронівська, Валенсія Миронівська, Постать одеська, Славен, МІП Дніпрянка, МІП Ассоль. Показник агрономічної стабільності Аs сортів пшениці озимої м'якої був 76,0-98,4 \%. Сорти пшениці ярої м'якої забезпечили формування врожайності на рівні 2,92-4,90 т/га, твердої $2,45-4,55$ т/га. Розмах варіювання $\mathrm{R}(\max -\min )$ відповідно становив 1,98 i 2,10 т/га, за коефіцієнта варіації 13,7 і 18,9 \% відповідно. Реалізація генетичного потенціалу продуктивності пшениці ярої м'якої в контрастні роки вирощування в середньому становила 44,0-71,0 \%, твердої - 36,5-61,7 \%. Найвищою генетичною гнучкістю $(\mathrm{Ymin}+\mathrm{Ymax}) / 2$ і найбільшою відповідністю до умов вирощування Північного Степу відзначались сорти пшениці ярої м'якої Злата (4,71 т/га), Струна Миронівська (4,75 т/га), Оксамит Миронівський (4,87 т/га), Світлана (5,27 т/га), твердої - Нащадок (4,39 т/га), Ізольда (4,24 т/га), Діана (4,00 т/га).

Ячмінь озимий та ярий $є$ основною зернофуражною культурою України. Одним із факторів одержання високих і стабільних урожаїв озимого ячменю є добір сортів, які здатні забезпечити стабільний збір врожаю за будь-яких погодних умов. В селекційних установах НААН створено нові сорти ячменю озимого, які належать до різних груп стиглості, характеризуються високою стійкістю до хвороб та вилягання, морозо-та холодостійкі, мають альтернативний тип розвитку та рівень продуктивності 9-10 т/га. Сорти ячменю озимого формували урожайність в середньому від 3,76 т/га до 6,95 т/га, розмах варіювання $\mathrm{R}(\max -\min )=3,19$ т/га, за коефіціснта варіації $21,7 \%$. Середня врожайність $(\mathrm{Y} \min +\mathrm{Y} \max ) / 2$ сортів ячменю озимого у контрастних умовах вирощування була від 4,33 т/га (2017 р.) до 8,61 т/га (2019 р.), а реалізація генетичного потенціалу продуктивності сортів становила 35,3-69,5 \%. Сорти, які відзначались високим адаптивним потенціалом забезпечували реалізацію генетичного потенціалу продуктивності від 4,89 т/га або 40,8 \% (2017р.) до 9,64 т/га або 80,3 \% (2019р.). Найвищою генетичною гнучкістю (Уmin + $\mathrm{Y}_{\max } / 2$ і найбільшою відповідністю до умов вирощування Північного Степу відзначались сорт Дев'ятий вал $(7,27$ т/га) та Снігова королева $(6,90$ т/га). При цьому, показник агрономічної стабільності As сортів ячменю озимого був на рівні $73,8-87,4$ \%. Умови Північного Степу 
України характеризуються нестійким, а в окремі періоди органогенезу ячменю ярого недостатнім зволоженням, високими температурами. Такий комплекс абіотичних чинників негативно впливає на ріст $\mathrm{i}$ розвиток рослин, а тому врожайність ячменю ярого у виробничих умовах залишається невисокою і нестабільної за роками при високій потенційній зерновій продуктивності сучасних сортів (8-9 т/га). В середньому за 2016-2020 pр. встановлено, що сорти різного екологічного походження формували урожайність в середньому від $3,21 \mathrm{т} /$ га до $5,84 \mathrm{t} /$ га, розмах варіювання $\mathrm{R}(\max -\min )=2,63 \mathrm{т} /$ га, за коефіцієнта варіації 11,0\%. Середня врожайність сортів ячменю ярого у контрастних умовах років досліджень $\left(\mathrm{У}_{\min }+\mathrm{У} \max \right) / 2$ змінювалась від 3,46 т/га (2018 р.) до 5,05 т/га (2015 р.), при реалізації генетичного потенціалу продуктивності сортів 40,1-62,5 \%. Сорти, які за своїми морфолого-біологічними особливостями були більш адаптивними до умов вирощування забезпечували реалізацію генетичного потенціалу в контрастні роки вирощування на рівні 50,4-79,6 \% (4,28-6,77 т/га). Вищою генетичною гнучкістю (Уmin + У $\max ) / 2$ характеризувались сорти пшениці Командор (5,06 т/га), Етикет $(5,20$ т/га), Виклик $(5,27 \mathrm{т} /$ га), Пан $(5,01 \mathrm{т} /$ га), Донецький $12(5,10$ т/га), Донецький 14 (5,15 т/га), Дорідний (5,09 т/га), МІП Мирний (5,01 т/га). Показник агрономічної стабільності As сортів ячменю ярого складав 61,7-98,3\%.

Висновки. В умовах Північного Степу України визначено параметри адаптивності, стресостійкості та виділено сорти Пшениці озимої м'якої, пшениці ярої м'якої та твердої та ячменю ярого i озимого, які здатні мають високий рівень реалізації генетичного потенціалу продуктивності.

\section{Література:}

1. Потенціал сортових ресурсів. Ефективне його використання головна передумова стабільного виробництва зерна / Мілютенко Т. Б. та ін. Насінництво. 2011. № 2. С. 1-6.

2. Лещук Н. В., Мажуга К. М., Орленко Н. С., Стариченко Є. М., \& Шкапенко Є. А. (2017). Comparative analysis of statistical software products for the qualifying examination of plant varieties suitable for dissemination. Plant Varieties Studying and Protection, 13(4), 429-435. https://doi.org/10.21498/2518-1017.13.4.2017.117757.

3. Москалець Т. 3. Прояв стабільності та пластичності генотипів пшениці м'якої озимої в умовах лісостепового екотопу. Вісник Украӥнського товариства генетиків і селекиіонерів. 2015. Т. 13, № 1. C. 51-55. 
4. Кочмарський В. С., Замліла Н. П., Вологдіна Г. Б.. Гуменюк О. В., Волощук С. І. Рівень адаптивності перспективних ліній пшениці м'якої озимої в умовах Лісостепу України. Миронівський вісник. 2016. Вип. 2. С. 98-116.

5. Солонечний П. М. Оцінка адаптивної здатності та стабільності сортів ячменю ярого за продуктивністю. Вісник Полтавської державної аграрної академії. 2014. № 4. С. 48-53.

6. Burdenyuk-Tarasevich, L. A., Dubova, O. A, Khahula, V. C. (2013) Evaluation of adaptive ability of soft winter wheat varieties in the conditions of the forest-steppe of Ukraine. Selektsia i nasinnystvo, 101, 3-11.

7. Khomenko, S. O., Fedorenko, I. V, Fedorenko, M. V. (2016) Homoeostasis and breeding value of collecting samples of soft wheat wheat for condi-tions of the forest-steppe of Ukraine. Myronivskyi visnyk, 3, 85-93.

DOI https://doi.org/10.30525/978-9934-26-111-4-48

\title{
ШПАРУВАТІСТЬ ГРУНТІВ ЗАПЛАВИ РІЧКИ УДИ
}

\author{
Казюта О. М. \\ кандидат сільськогосподарських наук, доцент, \\ доиент кафедри грунтознавства
}

Харківський національний аграрний університет імені В. В. Докучаєва

Казюта А. О.

кандидат сільськогосподарських наук, дочент кафедри трунтознавства

Харківський наиіональний аграрний університет імені В. В. Докучаєва с. Докучаєвське, Харківський район, Харківська область, Украйна

Територія заплави $\epsilon$ найбільш молодою порівняно 3 іншими елементами річкової долини. Тут відмічається висока динамічність усіх грунтово-екологічних процесів, що призводить до постійного активного розвитку грунтового покриву. Грунтовий покрив заплав характеризується просторовою варіабельністю, що $\epsilon$ наслідком складного рельєфу території заплави. Крім цього на диференційованість грунтів заплави впливає седиментація, трансформація речовин, флуктація рівня грунтових вод, комплекс 